\title{
The plasma cells in inflammatory disease of the colon: A quantitative study
}

\author{
J. M. SKINNER AND R. WHITEHEAD \\ From the Department of Pathology, Radcliffe Infirmary, Oxford
}

SYNOPSIS Immunoglobulin-containing cells have been counted in the mucosa of colectomy specimens from patients with ulcerative colitis and Crohn's disease. An increase in IgA cells occurs in both when compared with normal. In Crohn's colitis the increase is significantly higher than in ulcerative colitis. The importance of these findings in relation to pathogenesis is discussed.

Investigation into the immunological status of patients with ulcerative colitis and Crohn's colitis has provided data concerning circulating antibody levels to food antigens (Taylor and Truelove, 1961; Wright and Truelove, 1965, 1966), bacterial antigens (Lagercrantz, Hammarström, Perlmann, and Gustafsson, 1968; Thayer, Brown, Sangree, Katz, and Hersh, 1969), and colonic epithelial cell antigens (Broberger and Perlmann, 1959, 1962; Harrison, 1965; Marcussen and Nerup, 1973). Studies of peripheral blood lymphocyte transformation (Hinz, Perlmann, and Hammarström, 1967; Stefani and Fink, 1967) and lymphocyte cytotoxicity to colonic epithelium (Shorter, Spencer, Huizenga, and Hallenbeck, 1968; Watson, Quigley, and Bolt, 1963) have also been reported as well as responses in the skin to the application of dinitrochlorobenzene (DNCB) (Verrier-Jones, Housley, Ashurst, and Hawkins, 1969), tuberculin (Fletcher and Hinton, 1967), and Kveim reagent (Mitchell, Cannon, Dyer, Hinson, and Willoughby, 1970; Siltzbach, Vieira, Topilsky, and Janowitz, 1971). The results have not produced any clear-cut distinctions between the two diseases, on occasion have been contradictory, and in any case may not reflect the immunological status of the gut lymphoid tissue. More recently (1973) we have investigated the morphological evidence of immunoreactivity in the mesenteric lymph nodes of colectomy specimens in these two diseases without finding any significant differences. The criteria used for assessing lymph nodes, however, cannot be applied to that part of the peripheral lymphoid tissue in the gut wall which may well be playing the major role in the immunological response.

In normal circumstances the lamina propria of the Received for publication 20th May 1974. gut contains a preponderance of IgA-producing plasma cells; this IgA linked with secretor piece is the major component of the coproantibodies (Crabbé and Heremans, 1966; Tomasi, 1968). In order to assess immunological reactivity in the lamina propria in ulcerative colitis and Crohn's colitis we have quantitated the number of cells of each of the immunoglobulin classes (IgA, IgG, IgM, IgD, and IgE) and noted the presence or absence of secretor piece and any immune complexes containing the $\mathrm{C}_{3}$ component of complement.

\section{Material and Methods}

Fresh tissue from colectomy specimens from 85 patients was collected. The colectomy specimens were subsequently fixed and examined by routine histological methods and classified as either Crohn's disease or ulcerative colitis by the criteria of Lockhart-Mummery and Morson (1960). Six cases which could not confidently be categorized were put into a separate indeterminate group. Two cases so badly ulcerated that the mucosa was entirely lost were excluded as was one patient who was being treated with azathioprine which is known to suppress the number of plasma cells in the lamina propria (Campbell, Hersey, Harding, Hollingsworth, Skinner, and MacLennan, 1973). There were 82 cases available for analysis and as a control group full-thickness mucosal biopsies from 16 patients with the irritable colon syndrome and repeatedly normal mucosa histologically were examined.

Tissues from the colectomy specimens were selected so that they also included the full thickness of mucosa. Pilot studies confirmed that the SainteMarie technique (Sainte-Marie, 1962) was entirely 
suitable for use in our investigation. This entails fixation in cold alcohol $\left(4^{\circ} \mathrm{C}\right)$ followed by cold processing into paraffin wax. The method allows thin (3-5 $\mu$ ) sections to be cut ideally orientated perpendicular to the muscularis mucosa. The final stained product facilitates recognition of individual stained cells against a preserved histological mucosal architecture thereby constituting a significant advantage when counting over frozen section methods which are inherently predisposed to the diffusion of antibody and a less well preserved histological structure.

The immunofluorescent technique followed was basically that outlined by Nairn (1969) using all the appropriate controls. Direct fluorescein conjugates of antibodies to $\operatorname{IgA}$, IgG, IgM, and IgD which were raised in swine were obtained from Nordic Pharmaceuticals, Tilburg. Control, non-conjugated antibodies were obtained from the same source. Sheep antihuman IgE was obtained from the WHO immunoglobulin reference laboratory by the kindness of Drs Tomlinson and Taylor of the Public Health Laboratory Service. This was used in an indirect technique (Nairn, 1969) and localized using rabbit antisheep IgG conjugated with fluorescein (Nordic). The unlabelled anti- $\mathrm{C}_{3}$ and anti-secretor piece (Nordic) were also detected by the application of the rabbit antisheep IgG conjugate in the indirect technique. The stained sections were examined on a Leitz Ortholux microscope modified to provide blue light, dark-ground illumination (Tomlinson, 1970).

Quantitation was done by a modification of the point counting technique (Weibel, 1963). The sections were photographed at a magnification of $100 \times$ on Gaf Ansochrome 200 or Agfa 50L film, and 35 $\mathrm{mm}$ colour transparencies made. These were projected onto a point counting grid at a constant distance $(1.0 \mathrm{~m})$ from a projector with a $90 \mathrm{~mm}$ focal length lens. The grid was made of points at the corners of equilateral triangles 1.5 centimetres apart. The number of points falling on lamina propria were counted, this being proportional to the volume (Weibel, 1963). Within the same microscopical fields the number of plasma cells of each immunoglobulin class was counted directly and a ratio of plasma cells to points falling on lamina propria was calculated. To determine the number of points to be counted the summation average technique was used (Dunnill, 1968) and it was found that for a given specimen the ratio of plasma cells to points counted became constant within 4 to $5 \%$ when 1000 or more points fell on lamina propria. To achieve this between five and nine fields were examined and photographed. When, as in this investigation, all other factors are constant the volume of lamina propria defined by 1000 points is also constant, and we used this as the basic unit, expressing the results as plasma cells per 1000 points, ie, a fixed volume of lamina propria.

The method makes no attempt to assess absolute numbers in a given volume but so long as section thickness, magnification, and projection techniques remain constant the simple ratio of cells $/ 1000$ points allows valid comparisons to be made. Complicated calculations which depend on plasma cell size and section thickness (Crabbé and Heremans, 1966) and on variable tissue shrinkage due to differences in the histological components which are necessary in assessment of absolute numbers have thus been avoided.

The presence or absence of secretor piece in the epithelial cells and immune complexes in the lamina propria was noted at microscopy.

Cells producing IgD or IgE were present in such small numbers in both control and test cases that after the first 10 cases they were no longer counted.

\section{Results}

There are 46 cases of ulcerative colitis and 30 cases of Crohn's disease, leaving six indeterminate cases.

\begin{tabular}{|c|c|c|c|c|c|c|}
\hline \multicolumn{4}{|c|}{ Control $(n=16)$} & \multirow{2}{*}{$\begin{array}{l}\text { Ulcerative Colitis }(n=46) \\
2555 \\
1048 \\
3 \cdot 3737 \\
0 \cdot 2037\end{array}$} & \multirow{2}{*}{$\begin{array}{l}\text { Indeterminate }(n=6) \\
2675 \\
982 \\
3.3927 \\
0.2039\end{array}$} & \multirow{2}{*}{$\begin{array}{c}\text { Crohn's Disease }(n=30) \\
4735 \\
1367 \\
3.6536 \\
0.1490\end{array}$} \\
\hline $\operatorname{Ig} A$ & $\begin{array}{l}\text { mean } \\
\text { SD } \\
\text { meanlog } \\
\text { SD log }\end{array}$ & $\begin{array}{l}= \\
= \\
= \\
=\end{array}$ & $\begin{array}{r}896 \\
114 \\
2 \cdot 9491 \\
0 \cdot 0563\end{array}$ & & & \\
\hline IgG & $\begin{array}{l}\text { mean } \\
\text { SD } \\
\text { meanlog } \\
\text { SD log }\end{array}$ & $\begin{array}{l}= \\
= \\
= \\
=\end{array}$ & $\begin{array}{r}44 \\
21 \\
1 \cdot 5970 \\
0 \cdot 1952\end{array}$ & $\begin{array}{r}428 \\
233 \\
2 \cdot 4829 \\
0 \cdot 4698\end{array}$ & $\begin{array}{r}400 \\
317 \\
2 \cdot 4824 \\
0.3565\end{array}$ & $\begin{array}{r}465 \\
189 \\
2 \cdot 6304 \\
0 \cdot 1859\end{array}$ \\
\hline IgM & $\begin{array}{l}\text { mean } \\
\text { SD } \\
\text { meanlog } \\
\text { SD log }\end{array}$ & $\begin{array}{l}= \\
= \\
= \\
=\end{array}$ & $\begin{array}{r}28 \\
10 \\
1 \cdot 4043 \\
0 \cdot 1655\end{array}$ & $\begin{array}{r}243 \\
155 \\
2 \cdot 2516 \\
0 \cdot 4284\end{array}$ & $\begin{array}{r}334 \\
188 \\
2 \cdot 4560 \\
0 \cdot 2817\end{array}$ & $\begin{array}{r}245 \\
98 \\
2 \cdot 3569 \\
0 \cdot 1678\end{array}$ \\
\hline
\end{tabular}

Table I Plasma cell counts in groups of controls, ulcerative colitis, Crohn's colitis, and an indeterminate group shown by class of immunoglobulin ${ }^{1}$

${ }^{1}$ The figures are expressed as arithmetic mean and standard deviation and as mean and standard deviation of the logarithms. 
The results are shown in table I. The results for the control group, all the ulcerative colitis cases (UC), the indeterminate group (I), and Crohn's group (C) are shown expressed in arithmetical form as mean and standard deviation, and, as cells of the lymphocyte series population have a log-normal distribution, the mean and standard deviation of the logarithms are shown. Statistical analysis was performed using the logarithmic expressions.

As in normal individuals, so in the disease cases, the majority of cells in the lamina propria are of the IgA class. The IgA cells are increased in ulcerative colitis to a significant degree $(\mathrm{d}=12.8, \mathrm{P}<0.001)$ as are the IgG cells $(\mathrm{d}=10.5, \mathrm{P}<0.001)$ and the IgM cells $(\mathrm{d}=14.7, \mathrm{P}<0.001)$. The same is true of the indeterminate and Crohn's groups.

The IgA cell counts in Crohn's disease are higher than those in ulcerative colitis to a significant degree $(\mathrm{d}=6.91, \mathrm{P}<0.001)$ but this is not true of the IgG cells $(\mathrm{d}=1.90, \mathrm{P}>0 \cdot 10)$ or IgM cells $(\mathrm{d}=1.5, \mathrm{P}>0.05<0.10)$.

In table II the results logarithmically expressed for ulcerative colitis are shown subdivided into inactive disease ( 9 cases) and active disease ( 37 cases). In respect of the $\operatorname{IgA}$ cells there is a significant difference between these $(\mathrm{d}=6.94, \mathrm{P}<0.001)$, but a comparison of control and inactive ulcerative colitis shows no difference (using the $t$ test as numbers are smaller $(f=23, t=1.744, P>0.05<0.10)$. The same is true of the other immunoglobulin classes.

\begin{tabular}{lll}
\hline IgA & \multicolumn{2}{l}{ Ulcerative Colitis } \\
\cline { 2 - 3 } & Quiescent $(n=9)$ & Active $(n=37)$ \\
\hline Mean log & 3.0497 & 3.4415 \\
SD log & 0.1578 & 0.12503 \\
\hline
\end{tabular}

Table II Plasma cell counts for ulcerative colitis patients with active and quiescent disease

In table III the IgA results for Crohn's disease are shown subdivided into those cases with granulomas (17) and those without (13). There is no difference of any significance $(\mathrm{d} 1 \cdot 54, \mathrm{P}>0 \cdot 10)$.

\begin{tabular}{|c|c|c|}
\hline \multirow[t]{2}{*}{$\operatorname{IgA}$} & \multicolumn{2}{|l|}{ Crohn's Disease } \\
\hline & $\begin{array}{l}\text { With Granuloma } \\
(n=17)\end{array}$ & $\begin{array}{l}\text { Without Granuloma } \\
(n=13)\end{array}$ \\
\hline $\begin{array}{l}\text { Mean log } \\
\text { SD log }\end{array}$ & $\begin{array}{l}3 \cdot 6910 \\
0 \cdot 1223\end{array}$ & $\begin{array}{l}3 \cdot 6047 \\
0 \cdot 1707\end{array}$ \\
\hline
\end{tabular}

Table III Plasma cell counts in Crohn's disease with and without granulomata

\section{Discussion}

The inconclusive results of previous immunological studies probably reflect that it is in the gut lymphoid tissue, hitherto not adequately studied, that the most marked changes are seen. We have shown that in ulcerative colitis the number of $\operatorname{IgA}$ cells is increased, but not as much as in Crohn's disease. This is interpreted as showing that the gut 'immunocytes' are stimulated in both diseases and that the response is greater in Crohn's disease. Whatever the aetiological factors responsible for ulcerative colitis and Crohn's disease, these findings, made on bowel removed for established disease, may have an important bearing on pathogenesis. It may be that the same antigenic stimuli are in part responsible for the pathological findings in both diseases and would explain their similarities. It is possible that in ulcerative colitis an antigen-antibody reaction in the mucosa produces antigen-excess immune complexes of small size which are undetected by the techniques we used. These could well be associated with an Arthus-like inflammatory reaction characterized by a marked polymorphonuclear component. Evidence of small complexes in the circulation in ulcerative colitis has been provided by Jewell and MacLennan (1973). In Crohn's disease the larger number of IgA cells could mean that larger sized antibody-excess complexes are formed. These larger complexes are known to stimulate granuloma production and persist in them (Spector and Heesom, 1969). Furthermore the migration and subsequent death of macrophages and the release of the complexes they contain (Spector and Ryan, 1970) would initiate further granuloma formation and could explain the fullthickness lesion in Crohn's disease. The presence of antigen in the lumen, its entry into the bowel, and its subsequent combination with antibody might also explain the characteristic localization of Crohn's disease and ulcerative colitis to different sites in the bowel. Antigen, in the presence of high levels of antibody in Crohn's disease, would tend to be fixed in the more proximal intestine whereas in ulcerative colitis in the presence of lower antibody levels in the more distal intestine. Our inability to demonstrate complexes (even in the pilot study using frozen material) does not detract from this hypothesis because it is only in ideal circumstances, eg, renal glomeruli where background staining is minimal, that they can confidently be detected. But it is also possible that the complexes as investigated in serum are not complement fixing (Jewell and MacLennan, 1973), although Doe, Booth, and Brown (1973) found otherwise.

The results for the indeterminate group, as one could predict from the arguments put forward in the 
discussion, lie between ulcerative colitis and Crohn's disease.

\section{References}

Broberger, O., and Perlmann, P. (1959). Autoantibodies in human ulcerative colitis. J. exp. Med., 110, 657-674.

Broberger, O., and Perlmann, P. (1962). Demonstration of an epithelial antigen in colon by means of fluorescent antibodies from children with ulcerative colitis. J. exp. Med., 115, 13-26.

Campbell, A. C., Hersey, P., Harding, B., Hollingsworth, P. M., Skinner, J. M., and MacLennan, I. C. M. (1973). Effects of anticancer agents on immunological status. Brit. J. Cancer, 28, Suppl. 1, 254-261.

Crabbé, P. A., and Heremans, J. F. (1966). The distribution of immunoglobulin containing cells along the human gastrointestinal tract. Gastroenterology, 51, 305-316.

Doe, W. F., Booth, C. C., and Brown, D. L. (1973). Evidence for complement binding immune complexes in adult coeliac disease, Crohn's disease and ulcerative colitis. Lancet, 1, 402-403.

Dunnill, M. S. (1968). Quantitative methods in histology. In Rec. Advanc. clin. Path., Series V, 401-416.

Fletcher, J., and Hinton, J. M. (1967). Tuberculin sensitivity in Crohn's disease: a controlled study. Lancet, 2, 753-754.

Harrison, W. J. (1965). Autoantibodies against intestinal and gastric mucous cells in ulcerative colitis. Lancet, 1, 1346-1350.

Hinz, C. F., Jr., Perlmann, P., and Hammarström, S. (1967). Reactivity in vitro of lymphocytes from patients with ulcerative colitis. J. Lab. clin. Med., 70, 752-759.

Jewell, D. P., and MacLennan, I. C. M. (1973). Circulating immune complexes in inflammatory bowel disease. Clin. exp. Immunol., 14, 219-226.

Lagercrantz, R., Hammarström, S., Perlmann, P., and Gustafsson, B. E. (1968). Immunological studies in ulcerative colitis (iv) origin of autoantibodies. J. exp. Med., 128, 1339-1352.

Lockhart-Mummery, H. E., and Morson, B. C. (1960). Crohn's disease (regional enteritis) of the large intestine and its distinction from ulcerative colitis. Gut, 1, 87-105.

Marcussen, H., and Nerup, J. (1973). Fluorescent anti colon and organ specific antibodies in ulcerative colitis. Scand. J. Gastroent., 8, 9-15.

Mitchell, D. N., Cannon, P., Dyer, N. H., Hinton, K. F. W., and Willoughby, J. M. T. (1970). Further observations on Kveim test in Crohn's disease. Lancet, 2, 496-498.
Nairn, R. C. (1969). Fluorescent Antibody Tracing, 3rd Edition Livingstone, Edinburgh.

Sainte-Marie, G. (1962). A paraffin embedding technique for studies employing immunofluorescence. J. Histochem. Cytochem., 10, 250-256.

Shorter, R. G., Spencer, R. J., Huizenga, K. A., and Hallenbeck, G. A. (1968). Inhibition of in vitro cytotoxicity of lymphocytes from patients with ulcerative colitis and granulomatous colitis for allogeneic colonic epithelial cells using horse anti-human thymus serum. Gastroenterology, 54, 227-231.

Siltzbach, L. E., Vieira, L. O. B. D., Topilsky, M., and Janowitz, H. D (1971). Is there Kveim responsiveness in Crohn's disease? क Lancet, 2, 634-636.

Skinner, J. M., and Whitehead, R. (1973). A morphological assessment of immunoreactivity in colonic Crohn's disease and ulcerative colitis by a study of the lymph nodes. J. clin. Path. 27, 202-206.

Spector, W. G., and Heesom, N. (1969). The production of granulomata by antigen-antibody complexes. J. Path., 98, 31-39.

Spector, W. G., and Ryan, G. B. (1970). The mononuclear phagocyte in inflammation. In Mononuclear Phagocytes, edited by R. van Furth, pp. 219-232. Blackwell, Oxford.

Stefani, S, and Fink, S. (1967). The ulcerative colitis lymphocyte: reaction to $\mathrm{E}$ coli 014 and colon antigens. Scand. J. Gastroent. 2, 333-336.

Taylor, K. B., and Truelove, S. C. (1961). Circulating antibodies to milk proteins in ulcerative colitis. Brit. med. J., 2, 924-929.

Thayer, W. R., Jr., Brown, M., Sangree, M. H., Katz, J., and Hersh, T. (1969). Escherichia coli 0:14 and colon haemagglutinating antibodies in inflammatory bowel disease. Gastroenterology, $57,311-318$

Tomasi, T. B., Jr. (1968). Human immunoglobulin A. New Engl. J. Med., 279, 1327-1330.

Tomlinson, A. H. (1970). An interference filter for use with the iodine quartz lamp to excite fluorescence. In Standardisation in Immunofluorescence, edited by E. J. Holborow. Blackwell, Oxford.

Verrier-Jones, J., Housley, J., Ashurst, P. M., and Hawkins, C. F. (1969). Development of delayed hypersensitivity to dinitrochlorobenzene in patients with Crohn's disease. Gut, 10, 52-56.

Watson, D. W., Quigley, A., and Bolt, R. J. (1963). Effect of lymphocytes from patients with ulcerative colitis on human adult colon epithelial cells. Gastroenterology, 51, 985-993.

Weibel, E. R. (1963). Principles and methods for the morphometric study of the lung and other organs. Lab. Invest., 12, 131-155.

Wright, R., and Truelove, S. C. (1965). Circulating antibodies to dietary proteins in ulcerative colitis. Brit. med. J., 2, 142-144.

Wright, R, and Truelove, S. C. (1966). Auto-immune reactions in ulcerative colitis. Gut, 7, 32-40. 